\title{
Dynamic Membranes on Polysulfone Support for Fuel Cells
}

\author{
MIRCEA SEGARCEANU ${ }^{1}$, ALEXANDRA RALUCA MIRON ${ }^{1}$, SZIDONIA KATALIN TANCZOS ${ }^{2}$, ABBAS ABDUL KADHIM KLAIF RIKABI ${ }^{1,3}$, \\ ION MARIUS NAFLIU', DANUT IONEL VAIREANU ${ }^{1 *}$ \\ ${ }^{1}$ Politehnica University of Bucharest, Faculty of Applied Chemistry and Materials Science, Dept. of Analytical Chemistry and \\ Environmental Engineering, 1-7, Gheorghe Polizu Str., Bucharest, 011061, Romania \\ 2 Sapientia University, Libertatii Str., 500104, Mircurea Ciuc, Romania \\ ${ }^{3}$ Technical college of Al-Mussaib (TCM), Al-Furat Al-Awsat Technical University, Foundation of Technical Education, Baghdad, \\ Iraq
}

\begin{abstract}
In the present paper, the authors dealt with the synthesis and characterization of a new type of dynamic membrane with polysulfone matrix and ionic polymer electrolyte: polysulfone-sulfonated polyetherethersulfone (PSf-SPEEK). The PSF-SPEEK composite membranes were formed by ultrafiltration of SPEEK gel on the polysulfone matrix in a CELFA System installation. The thickness of the PSf porous layer for the different membranes can be between 50 and $120 \mu \mathrm{m}$. The variation of SPEEK active layer's thickness is dependent both on the concentration of the SPEEK solution in the feed, and on the velocity of the surface flow. The sulfonated polymer (SPEEK) superficial layer ranges from 35 to $75 \mathrm{~nm}$, being thicker at low flow rates having a slight increasing related to the increase-of the SPEEK concentration. Increasing the polymer concentration; from 0.5 to $2.5 \%$, used in the feed solution leads to a doubling of the conductivity and a tripling of the ion exchange capacity. The maximum conductivity of the PSF-SPEEK dynamic composite membranes is $0.234 \mathrm{~S} / \mathrm{cm}$ and the ion exchange capacity is $1.682 \mathrm{meq} / \mathrm{g}$.
\end{abstract}

Keywords: composite membranes, polysulfone, polysulfone-sulfonated polyetherether sulfone, fuel cell

The synthesis and characterization of new types of polysulfone-based composite membranes for potential use in green technologies (fuel cells, accumulators, ultrafiltration, biomedicine, etc.) are developed, in the context of increased interest in obtaining polymeric membranes with improved performance, economically viable and technologically applicable [1-3]. The membrane is defined as an interphase barrier that restricts the transport of different chemical species, in a selective manner [3-5]. A membrane may be homogeneous or heterogeneous, having either a symmetrical or asymmetrical structure, be it solid or liquid. It can carry either positive or negative charges, be neutral or bipolar $[6,7]$.

Along with positive and / or negative charges an ion exchange membrane is characterized by: ion exchange capacity, conductivity, thermal resistance and aggressive environments [8-10].

The main types of membranes are:

-isotropic membranes, that can further classify in:

- microporous membranes,

- mesoporous dense membranes,

- nanoporous membranes,

-electrically charged membranes,

-non-isotropic membranes, with the following sub-types:

- Loeb-Sourirajan membranes,

- composite membranes,

- liquid supported membranes [11,12].

Composite membranes are membranes that consist of two materials with different characteristics. One of them confers physicochemical resistance while the other offers selectivity [13-15]. One of the least studied types of composite membranes is the one obtained by micro- or ultra-filtration $[16,17]$. Since 1970 's Kesting noted that due to the ultrafiltration process of polymer solutions, a fine selective layer of micron thick is formed on the support membranes $[2,5,18,19]$.

This new type of composite membrane, also called dynamic membrane, has found little use in baromembrane processes (ultrafiltration, nanofiltration or reverse osmosis) due to hydrodynamic damages $[20,21]$. The way membranes work and are exploited in fuel cells opens a new road to dynamic membranes [22].

In the present paper the authors deal with the synthesis and characterization of a new type of dynamic membrane with polysulfone matrix and ionic polymer electrolyte. This is the polysulfone-sulfonated polyetherether sulfone (PSfSPEEK).

\section{Experimental part}

Materials, methods and apparatus

Polysulfone (PSf) Udel type (Aldrich - M = $22000 \mathrm{Da}$ ), was used as basic material for all the variants of membranes prepared with solvent purchase from Merck: dimethylformamide (DMF). Poly ether ether ketone (PEEK - 350P, gray powder, $M W=28.000 \mathrm{D}$ ) was dried in a vacuum oven at $100^{\circ} \mathrm{C}$. The water required for solution preparation was obtained with a Millipore System. All the necessary solvents were purchased from Merck, namely: acetone, lower aliphatic alcohols (methanol, ethanol and isopropanol).

Morphological analysis of samples was performed by scanning electron microscopy (SEM). It used a highresolution microscope, a FEl Instrument with dual beam being equipped with X-ray (EDX) dispersive detector. The samples were covered with a thin layer of gold.

\section{PSF-SPEEK dynamic membranes}

PEEK pellets (2-8 g) were gradually added to $100 \mathrm{~mL}$ $\mathrm{H}_{2} \mathrm{SO}_{4}(96 \%)$ Merck, under vigorously stirring, at room temperature (approx. $22^{\circ} \mathrm{C}$ ). After the 10 -day maturation period, the sulphonate polymer was recovered by precipitating the polymeric acid solution in a large amount of water (ice) under mechanical stirring for a period of time ranging from one to two hours. The formation of a white gel - SPEEK was observed.

\footnotetext{
* email: di_vaireanu@yahoo.co.uk
} 
The SPEEK gel was left to stabilize overnight. SPEEK was washed with deionized water by introducing the polymers into a dialysis tube and the dialysis of the acid from the polymers until the wash water reached a $\mathrm{pH}$ value between 6 and 7 [21-23].

The PSf-SPEEK composite membranes were formed by SPEEK gel ultrafiltration in a CELFA System installation on the polysulfone matrix $[24,25]$.

\section{Membrane conductivity}

Membrane conductivity, km, was measured under atmospheric pressure and in membrane thickness by the $A C$ method [26, 27]. The membrane resistance (R) was determined by subtracting the resistance of the electrolytic solution (Rs is solution resistance measured without membrane) from the resistance of the balanced membrane in the electrolytic solution $\left(R_{s+m}\right)$ :

$$
R=R_{s+m}-R_{s}
$$

Proton conductivity was calculated by measuring the impedance of the membrane $\mathrm{R}(\mathrm{Ohm})$ using an RLC measurement device, using the following relationship:

$$
\kappa_{m}=\frac{1}{S_{m}\left(R_{s+m}-R_{s}\right)}
$$

where: $\mathrm{km}$ is proton conductivity [Scm-1], I is the thickness of the membrane $[\mathrm{cm}], S_{m}$ is the area of the membrane section $\left[\mathrm{cm}^{2}\right]$ (having $1 \mathrm{~cm}$ in diameter) and $R$ is the impedance [Ohm] measured at the frequency of $1 \mathrm{KHz}$ in continuous current $[24,28]$.

\section{Ion exchange capacity (CSI)}

Ion exchange capacity is determined by titration the composite membrane with potassium hydroxide, while in an inert atmosphere (1 $\mathrm{g}$ polymeric membrane). The ion exchange capacity is expressed in milliequivalents per gram of solid polymer (meq / g) [29,30].

\section{Hydrodynamic characteristics}

The determination of volume fluxes of SPEEK solution was obtained using equation (3):

$$
J=\frac{V}{S \cdot t}\left(\mathrm{~L} / \mathrm{m}^{2} \mathrm{~h}\right)
$$

where: $V$ is the permeate volume $(L), S$ is the effective surface area of the membrane $\left(\mathrm{m}^{2}\right)$ and $t$ is the time required to collect the permeate volume $(h)[31,34]$.

\section{Results and discussions}

Ultrafiltration is the separation operation most commonly used in membrane technology [35-37]. Separations by ultrafiltration are mainly due to a sieving process, so that the quantitative treatment of the separation operation can be done by treating the transport phenomenon as a continuous phase flow process through a porous membrane material [ 35,36$]$. By ultrafiltration are separated the ultrafiltrate (permeate) - consisting of the solvent and the low molecular weight substance which crosses the membrane and the retentate which represents the fraction enriched in macromolecular species that are retained on the membranes (fig. 1)[37].

Dynamic membranes are obtained in situ through retaining within the support membrane of the colloidal particles or macromolecules, which caused the formation of a finely uniform active layer and offered a high selectivity, determined by the properties of the macromolecules: ion exchange, complexing, biospecific interaction $[37,38]$.

Ultrafiltration uses membranes with asymmetric structure, containing a thin active layer (0.1-1 $\mu \mathrm{m})$ which allows large hydraulic permeabilities and a thick porous layer $(80-150 \mu \mathrm{m})$ which offers the membrane good mechanical properties [35, 37]. A schematic diagram for the ultrafiltration process is given in figure 2 . The related devices are depicted in there: the feed pump, the circulation pump and the turbine.

The variables of the conducted study can be determined depending upon [39-47]:

-the characteristics of the solution to be separated,

-the operational parameters: flow, pressure differences and flow velocity.

\section{Dimensional analysis of PSf-SPEEK composite membranes}

The determination of membranes characteristic dimensions (thickness, diameter, pore length and shape) is achieved using electronic scan microscopy images presented in figure 3. It must be emphasized that the membranes are examined in vacuum, so in dry state. That is why in the applications in which they are trained they can often undergo dimensional changes, most often due to swelling $[20,21]$.

As it can be seen in figure 3, the thickness of the PSf porous layer for different membranes ranges from 50 and $120 \mu \mathrm{m}$.

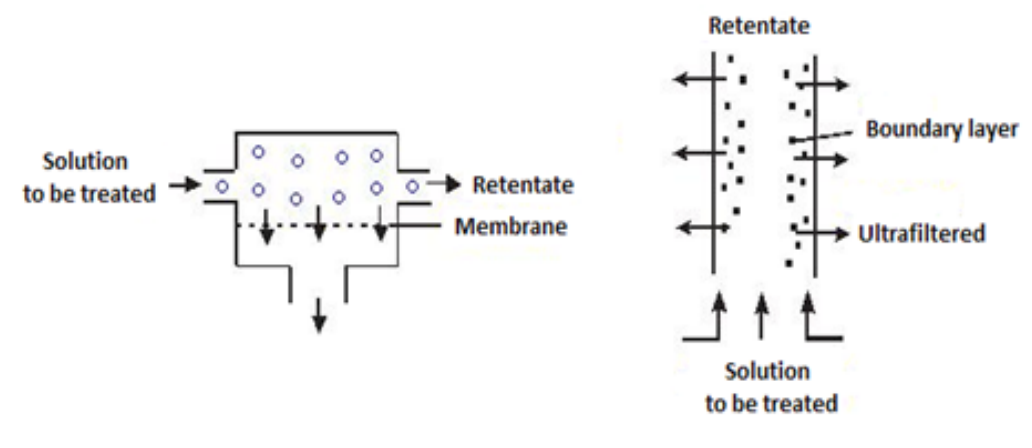

Fig. 1. Ultrafiltration principle scheme: a-plane membrane; b-tubular membrane

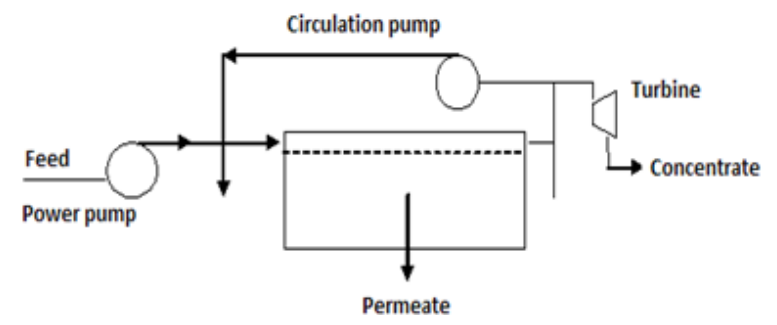

Fig. 2. The scheme of the ultrafiltration plant 


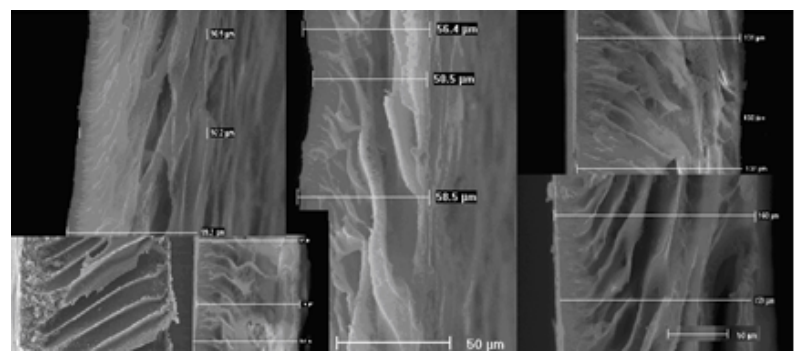

Fig. 3. Ways of measuring the thickness of layers of composite membranes $[20,21]$

Figure 4 shows in sight (fig. 4a) sulfonated poly ether ether ketone gels at concentrations of $0.5 ; 1.5$ and $2.5 \%$ as well as the PSf-SPEEK composite membranes obtained based on these gels (fig. $4 \mathrm{~b}$ and $\mathrm{c}$ ). Membrane compactness increases with SPEEK concentration used in ultrafiltration in order to obtain dynamic composite membranes.

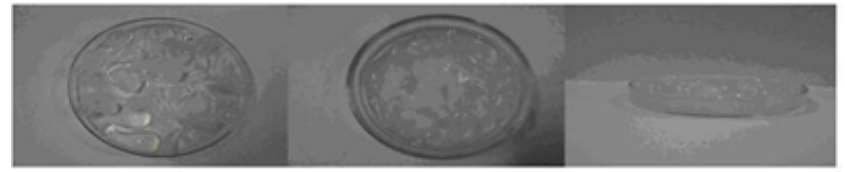

$a_{1}$

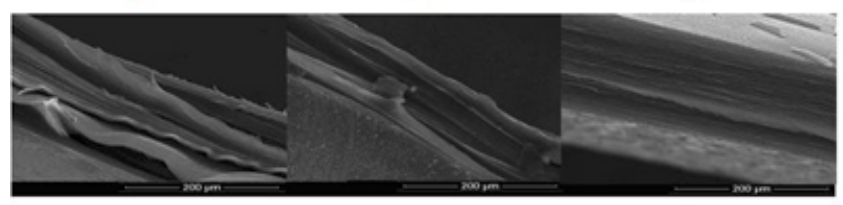

$b_{1}$

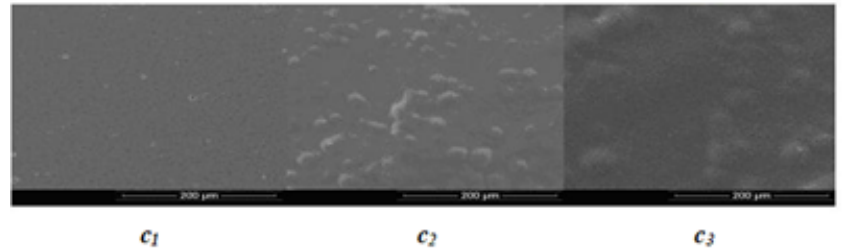

$c_{1}$
Fig. 4. SPEEK gels appearance (a1-0.5\%; a2-1.5\% si a3-2.5\%) and SEM images of the composite membranes obtained on the basis of SPEEK gels (b-section and c-active layer)

The variation of SPEEK active layer thickness is depicted in figure 5 . The figure shows its dependency both on the SPEEK solution concentration in the feed and on the surface flow velocity.

Itcan be noted that the superficial layer of the sulfonated polymer (SPEEK) stays between 35 and $75 \mathrm{~nm}$, being thicker at low flow rates and slightly increasing once the SPEEK concentration increases.

Permeate flow for PSf-SPEEK composite membranes Volume flow of permeate depends on working pressure (betw een 1 and $9 \mathrm{~atm}$ ), but also on SPEEK concentration (between 0.5 and $2.5 \%$ ) (fig. 6).

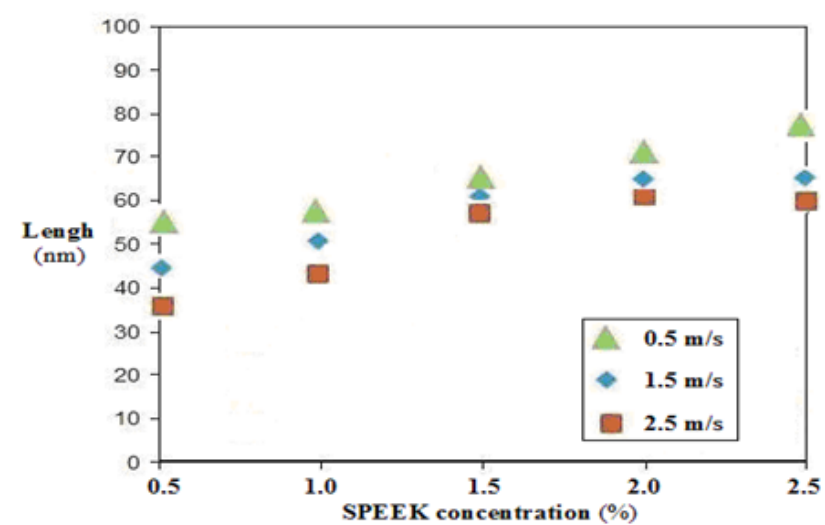

Fig. 5. The thickness of SPEEK composite membranes layer

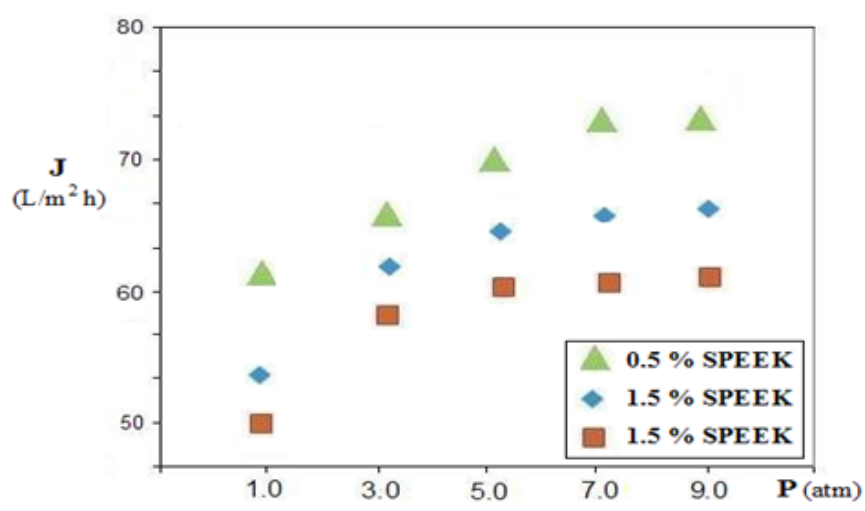

Fig. 6. Permeate flow according to working pressure and SPEEK concentration in feed

Flow values are specific for ultrafiltration of relatively concentrated polymeric solutions (gels) ranging from 50 to $72 \mathrm{~L} / \mathrm{m} 2 \mathrm{~h}$. Increasing the transmembrane pressure leads to an increase in flow up to $5 \mathrm{~atm}$, after which a plateau is obtained, which occurs more rapidly at higher concentrations of SPEEK.

Ion exchange capacity and conductivity of PSF-SPEEK composite membranes

The essential characteristic of PSf-SPEEK composite membranes when using them in the construction of fuel cells is ionic conductivity, in our case the protonic conductivity.

PSf-SPEEK dynamic composite membranes subjected to the tests were obtained under similar working pressure conditions of $5 \mathrm{~atm}$, flow rate of $2 \mathrm{~m} / \mathrm{s}$, surface feed and polymeric support, $12 \%$ polysulfone in DMF.

Practically, increasing the concentration of the polymer used in the feed solution leads to a doubling of conductivity and $a$ tripling of ion exchange capacity. The maximum conductivity of the PSf-SPEEK dynamic composite membranes is $0.234 \mathrm{~S} / \mathrm{cm}$ and the ion exchange capacity is $1.682 \mathrm{meq} / \mathrm{g}$.

Table 1

CHARACTERISTICS OF DIFFERENT TYPES OF MEMBRANES

\begin{tabular}{|l|c|c|}
\hline Membrane type & $\begin{array}{c}\text { Ion Exchange Capacity } \\
\text { (meq/g) }\end{array}$ & $\begin{array}{c}\text { Conductivity } \\
\sigma(\mathrm{S} / \mathrm{cm})\end{array}$ \\
\hline PSf-SPEEK $0.5 \%$ & 0.547 & 0.122 \\
\hline PSf-SPEEK $1.0 \%$ & 0.725 & 0.145 \\
\hline PSf-SPEEK 1.5\% & 0.965 & 0.188 \\
\hline PSf-SPEEK 2.0\% & 1.520 & 0.209 \\
\hline PSf-SPEEK 2.5\% & 1.682 & 0.234 \\
\hline
\end{tabular}




\section{Conclusions}

In the present paper, the authors discussed about the synthesis and characterization of a new type of dynamic membrane with polysulfone matrix and ionic polymer electrolyte, namely polysulfone-sulfonated polyetherether sulfone (PSf-SPEEK). The PSf-SPEEK composite membranes were formed by ultrafiltration of SPEEK gel on the polysulfone matrix in a CELFA System installation.

The thickness of the PSf porous layer for different membranes resides between 50 and $120 \mu \mathrm{m}$. The variation of SPEEK active layer thickness is mainly dependent on the concentration of the SPEEK solution in the feed, but also depends on the surface flow velocity. The sulfonated polymer (SPEEK) superficial layer ranges from 35 to 75 $\mathrm{nm}$, being thicker at low flow rates and slightly increasing with increasing SPEEK concentration. Increasing the polymer concentration, from 0.5 to $2.5 \%$, used in the feed solution leads to a doubling of the conductivity and a tripling of the ion exchange capacity.

Finally, the computations showed a maximum conductivity of the PSf-SPEEK dynamic composite membranes of $0.234 \mathrm{~S} / \mathrm{cm}$ as well as an ion exchange capacity of $1.682 \mathrm{meq} / \mathrm{g}$.

\section{References}

1.RAUTENBACH R., ALBRECHT, R., Membrane Processes, J ohn Wiley, New York, 1989.

2.KESTING, R.E., Synthetic Polymeric Membranes, McGraw Hill, New York, 1985.

3.STAMATIALIS, D.F., PAPENBURG, B.J., GIRONES, M., SAIFUL, S., BETTAHALLI, S.N.M., SCHMITMEIER, S., WESSLING, M., J ournal of Membrane Science, 308, no. 1-2, 2008, p. 1.

4.STRATHMAN, H., Synthetic membranes and their preparation, in: M.C. PORTER (Ed.), Handbook of industrial membrane technology, 1990.

5.MULDER, M., Basic Principles of Membrane Technology, Kluwer Academic Publishers, Dordrecht, 1997.

6.NECHIFOR, G., POPESCU, G., Rev. Roum. Chim., 35, no. 7-9, 1990, p. 899.

7.LOEB, S., SOURIRAJAN, S., Adv. Chem.Ser., 38, 1963, p.117

8.KESTING, R.E., J. Appl. Polym. Sci, 17, 1973, p.1771

9.van OSS, G.J., Progress in Separation and Purification (E.S. Perry si C.J. van Oss, Ed.), Interscience, New York, 1970

10.HWANG, S.T., Kammermeyer, K., Membranes in Separations, J ohn Wiley, New York, 1975

11.MEARES, P., Membrane Separation Processes, Elsevier Scientific Publ. Co., Amsterdam, 1976

12.PERRY, E.S., ed. Separation and Purification, Plenum Press NewYork, 1978

13.CRACIUN, M. E., MIHAI, M., NECHIFOR, G., Environmental Engineering and Management J ournal, 8, no. 4, 2009, p. 771.

14.NECHIFOR, G., VOICU, S.I., NECHIFOR, A.C., GAREA, S., Desalination, 241, no. 1-3, 2009, p. 342.

15.POPESCU, G., NECHIFOR, G., ALBU, B., LUCA, N., Rev. Roum. Chim , 34, no. 2, 1989, p. 577.

16.NECHIFOR, G., LUCA, N., POPESCU, G., NECHIFOR, M., Rev. Roum. Chim., 34, no. 11-12, 1989, p. 2047.

17.SEGARCEANU, M., A.R., MIRON, LICA, C.G., OPREA, O., RIKABI, A.A.K.K., VAIREANU, D.I., Rev. Chim. (Bucharest), 69, no. 4, 2018, p. 772.

18.NECHIFOR, G., ALBU, B.G., RATA, D., POPESCU, G., Rev. Chim. (Bucharest), 47, no. 3, 1996, p. 260.

19.SASTRE, A.M., KUMAR, A., SHUKLA, J.P., SINGH, R.K., Sep. Purif. Meth., 27, 1988, p. 213.

20.VOICU, S.I., ALDEA, F., NECHIFOR, A.C., Rev. Chim. (Bucharest), 61, no. 9, 2010, p. 817.
21.NECHIFOR, A.C., PANAIT, V., NAFTANAILA, L., BATALU, D., S.I., VOICU, Digest Journal of Nanomaterials and Biostructures, 8, no. 2, 2013, p. 875.

22.RIKABI, A.A.K.K., NECHIFOR, A.C., MOHAMMED, T.J ., OPREA, O., MIRON, A.R., SEGARCEANU, M., VAIREANU, D.I., Rev. Chim. (Bucharest), 67, no. 8, 2016, p. 1489

23.RIKABI, A.A.K.K., CUCIUREANU, A., CHELU, M., MIRON, A.R., ORBECI, C., POPA, A.G., CRACIUN, M.E., Rev. Chim. (Bucharest), 66, no. 8, 2015, p. 1093

24.RIKABI, A.A.K.K., BALABAN (CHELU), M., HARABOR, I., ALBU, P.C., SEGARCEANU, M., NECHIFOR, G., Rev. Chim. (Bucharest), 67, no. 9, 2016, p. 1658

25.BAICEA, C., LUNTRARU, V., VAIREANU, D., VASILE, E., TRUSCA, R., Open Chemistry, 11, no. 3, 2013, p. 438.

26.LICA, C.G., SEGARCEANU, M., PLESCA, M., RIKABI, A.A., NECHIFOR, G., UPB Scientific Bulletin, Series B: Chemistry and Materials Science , 76, no. 3, p. 151.

27.NECHIFOR, A.C., LICA, C.G., KOTER, S., OLTEANU, C., COSTACHE, L.N., TOTU, E.E., J ournal of Optoelectronics and Advanced Materials, 15,2013, no. 7-8, p. 639.

28.LICA, C.G., NECHIFOR, A.C., KOTER, S., OLTEANU, C., COSTACHE, L.N., Rev. Chim. (Bucharest), 64, 2013, no. 6, p. 565.

29.BAICEA, C., NECHIFOR, A.C., VAIREANU, D.I., GALES, O., TRUSCA, R., VOICU, S.I., Optoelectronics and Advanced Materials-Rapid Communications 5, no. 11, 2011, p. 1881.

30.MACDONALD, J. R., Impedance Spectroscopy- emphasizing solid materials and systems, J ohn Wiley and Sons, USA, 1987.

31.J ONSCHER, A. K., Dielectric relaxation in solids, Chelsea Dielectric Press, London, (1983).

32.VOICU, S.I., STANCIU, N.D., NECHIFOR, A.C., VAIREANU, D.I., NECHIFOR, G., Semiconductor Conference, 2008. CAS 2008. International 2, p. 245.

33.CUCIUREANU, A., BATRINESCU, G., BADEA, N.N., RADU, D.A., NECHIFOR, G., Mat. Plast., 47, no. 4, 2010, p. 416.

34.BATRINESCU, G., CONSTANTIN, M.A., CUCIUREANU, A., NECHIFOR, G., Polymer Engineering and Science, 54(7), 2014, p. 1640, DOI: 10.1002/ pen.23707.

35.NEAGU, E., ROMAN, G.P., RADU, G.L., NECHIFOR, G., Romanian Biotechnological Letters, 15(1), 2010, p. 5042.

36.NECHIFOR, G., POPESCU, G., LUCA, N., Rev. Roum. Chim., 39, no. 8, 1994, p. 885.

37.GARGANCIUC, D., BATRINESCU, G., NECHIFOR, G., OLTEANU, M., Mat. Plast., 45, no. 1, 2008, p. 29

38.NECHIFOR, A.C., NAFTANAILA, L., RIKABI, A.A.K.K., DINU, A., PANAIT, V., MIRON, A.R., Rev. Chim. (Bucharest), 65, no. 4, 2014, p. 386.

39.AL ANI, H.N.A., CIMBRU, A.M., TRISCA-RUSU, C., TANCZOS, S.K.., CUCIUREANU, A., NECHIFOR, A.C., Rev. Chim. (Bucharest), 68, no. 2, 2017, p. 203

40.AL ANI, H.N.A., CIMBRU, A.M., TANCZOS, S.K.., DIN, I.S., CUCIUREANU, A., NAFLIU, I.M., NECHIFOR, G., Rev. Chim. (Bucharest), 68, no. 3, 2017, p. 427

41.DRIOLI, E., NAKAGAKI, M., Plenum Press, New York, 1986, p .215. 42.WODZKI, R., SWIATKOWSKI, M., PRETULA, J., KALUZINSKI, K., J.Appl. Polym. Sci., 2004, 93, p. 1436.

43.SASTRE, A.M., KUMAR, A., SHUKLA, J.P., SINGH, R.K., Sep. Purif. Meth., 27, 1988, p. 213.

44.AL ANI, H.N.A., CIMBRU, A.M., DIN, I.S., TANCZOS, S.K., NAFLIU, I.M., CUCIUREANU, A., Mat. Plast., 54, no. 2., 2017, p. 353.

45.GHIMPUSAN, M., NECHIFOR, G., SPIRIDON, I., NECHIFOR, A.C., PASSERI, P., Mat. Plast., 53, no.4, 2016, p. 578.

46.GHIMPUSAN, M., NECHIFOR, G., NECHIFOR, A.-C., DIMA, S.-O., PASSERI, $P_{.}$, J ournal of Environmental Management, 203, 2017, p. 811. 47.VOICU, S.I., STANCIU, N.D., NECHIFOR, A.C., VAIREANU, D.I., NECHIFOR, G., Romanian Journal of Information Science and Technology 12(3), 2009, p. 410.

$\overline{\text { Manuscript received: } 15.01 .2018}$ 